\section{DNase I Activity Retained after Heat Inactivation in Standard Buffer}

\section{BioTechniques 29:38-42 (July 2000)}

For the detection of RNA transcripts by RT-PCR, prior removal of genomic DNA must be performed. To remove genomic DNA, RNA is often prepared by DNase I digestion following phenol extraction. Recently, one-tube or onebuffer systems of RT-PCR were developed to prevent loss of RNA and to reduce the risk of contamination $(2,6)$. In these methods, DNase I is added before RT. Taq DNA polymerase preparations could be a source of genomic DNA contamination in PCR (9). DNase I treatment of Taq DNA polymerase is recommended particularly when the primers for the highly conserved 16S rRNA gene are used $(7,8)$. Digestion of Taq enzyme with DNase I (4 U DNase I/10 $\mathrm{U}$ Taq DNA polymerase in a $10-\mu \mathrm{L}$ volume) was recommended by Rochelle et al. (8) to remove DNA contamination of the enzyme preparation. In each of these methods, DNase I in the reaction mixture was inactivated by heating at $75^{\circ} \mathrm{C}-95^{\circ} \mathrm{C}$ for $5-10 \mathrm{~min}$. The heated
DNase I solution was then carried over to the next PCR step $(3,4)$. We show here that the buffers used for the heat inactivation are crucial. Heating in PCR buffer alone is inadequate to inactivate DNase I.

Taq DNA polymerase (AmpliTaq ${ }^{\circledR}$; PE Biosystems, Urayasu, Chiba, Japan) was treated with DNase I (Nippon Gene, Toyama, Toyama, Japan) (4 U DNase I/10 U Taq DNA polymerase in $40 \mu \mathrm{L} \mathrm{PCR}$ buffer) at $37^{\circ} \mathrm{C}$ for $30 \mathrm{~min}$. The mixture was heated at $95^{\circ} \mathrm{C}$ for 10 min to inactivate DNase I and then used for PCR. The Taq DNA polymerase treated with DNase I required 100-fold more template DNA than the untreated Taq DNA polymerase for producing the same intensity of the band (data not shown). We suspect this was due to the activity of the DNase I, which remained active after the heat inactivation. To test this possibility, $50 \mathrm{ng}$ EcoRI-cleaved pBR322 was treated with $0.2 \mathrm{U} / 50 \mu \mathrm{L}$ or $1 \mathrm{U} / 50 \mu \mathrm{L}$ DNase I that had been heated for various periods. The treatment condition was either incubation at $37^{\circ} \mathrm{C}$ for $60 \mathrm{~min}$ or a thermal cycling program consisting of 30 cycles at $94^{\circ} \mathrm{C}$ for $30 \mathrm{~s}, 55^{\circ} \mathrm{C}$ for $30 \mathrm{~s}$ and $72^{\circ} \mathrm{C}$ for $30 \mathrm{~s}$. Using $0.2 \mathrm{U} / 50 \mu \mathrm{L}$ DNase I, which was recommended by
Rochelle et al. (8), degradation of DNA was observed within $20 \mathrm{~min}$ in both assay conditions (Figure 1A). With 1 U/50 $\mu$ L DNase I, Fiorenza and Mangia (3) and Huang et al. (4) used 1 U/50 $\mu \mathrm{L}$ and $2.5 \mathrm{U} / 50 \mu \mathrm{L}$ DNase I in RT conditions, respectively. DNA degradation was observed even in 90-min heated samples in the former assay condition and with 40 min of heating in the latter condition (data not shown). These experiments showed that DNase I in PCR buffer could not be completely inactivated by heating at $95^{\circ} \mathrm{C}$ for $10 \mathrm{~min}$.

Heating at $95^{\circ} \mathrm{C}$ for $10 \mathrm{~min}$ in the Tris-HCl buffer ( $\mathrm{pH} 8.3$ ) included in the Taq DNA polymerase kit failed to inactivate DNase I, but heating in the sodium acetate buffer ( $\mathrm{pH}$ 5.2) included in the DNase I kit or in the Tris-HCl buffer ( $\mathrm{pH}$ decreased to 5.2) did so. As the $\mathrm{pH}$ was different between these buffers, we examined the effect of $\mathrm{pH}$ on heat treatment of DNase I in PCR buffer. In the $\mathrm{pH}$ range of 7.0-8.5, $20 \mathrm{U} / 40 \mu \mathrm{L}$ DNase I were active after heating at $95^{\circ} \mathrm{C}$ for 10 min. However, DNase I was inactivated after heating in $\mathrm{pH}$ lower than 5 or higher than 9 (Figure 1B). The efficient heat inactivation of DNase $\mathrm{I}$ in acidic conditions agreed with both Kunitz's earlier observation (5) and the observa-

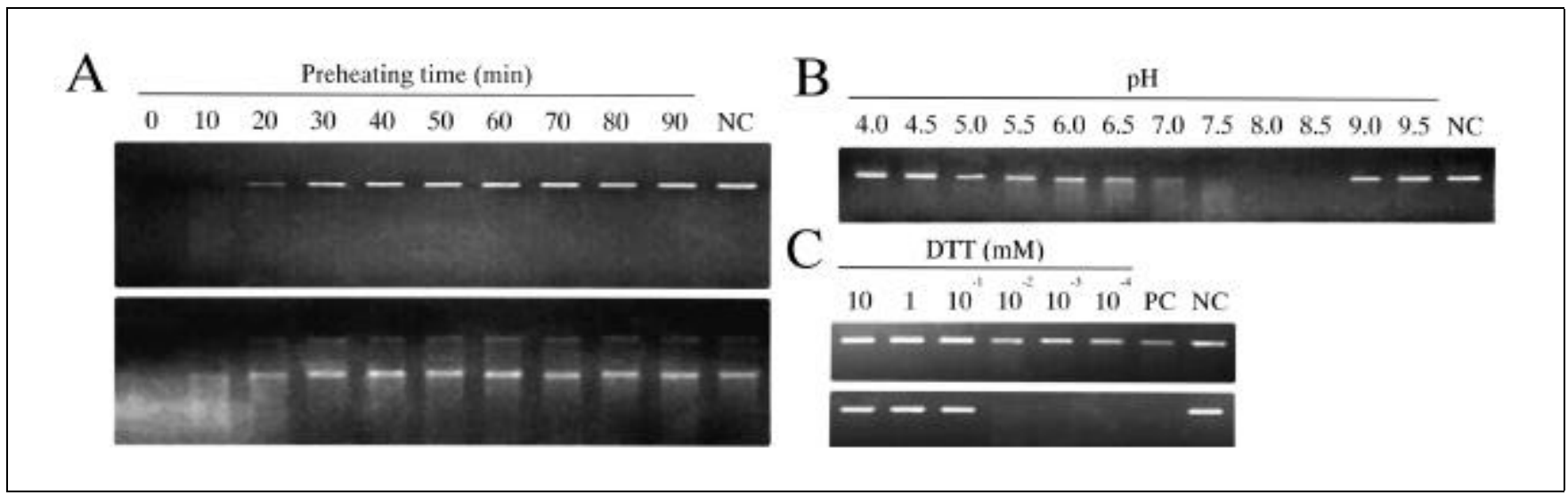

Figure 1. Effect of pH and DTT on the heat inactivation of DNase I. (A) DNase I in an amount of $0.2 \mathrm{U} / 20 \mu \mathrm{L}$ PCR buffer $[1.5 \mathrm{mM} \mathrm{MgCl}, 10 \mathrm{mM}$ Tris-HCl $\left(\mathrm{pH} 8.3\right.$ ) and $50 \mathrm{mM} \mathrm{KCl}$; GeneAmp ${ }^{\circledR}$ PCR buffer I (PE Biosystems)] was heated at $95^{\circ} \mathrm{C}$ for $0-90 \mathrm{~min}$. Digestion of $50 \mathrm{ng}$ EcoRI-cleaved pBR322 (New England BioLabs, Beverly, MA, USA) by DNase I was tested by incubating at $37^{\circ} \mathrm{C}$ for $60 \mathrm{~min}$ (upper panel) or in the thermal cycling program described in the text (lower panel). Fifteen-microliter aliquots were electrophoresed on a $1.5 \%$ agarose gel. The gels were stained with ethidium bromide $(1 \mathrm{mg} / \mathrm{L})$, and the bands were visualized by Foto/Analyst ${ }^{\mathrm{TM}}$ Investigator Eclipse systems (Fotodyne, Hartland, WI, USA). NC indicates omission of DNase I from the reaction mixture. In the lower panel, two bands were detected in each lane; the upper one represents the dsDNA and the lower one represents the ssDNA. (B) Twenty microliters of PCR buffer containing $20 \mathrm{U}$ DNase I were adjusted to different $\mathrm{pH}$ at $23^{\circ} \mathrm{C}$, heated at $95^{\circ} \mathrm{C}$ for 10 min, mixed with $20 \mu \mathrm{L}$ PCR buffer containing $100 \mathrm{ng}$ EcoRI-cleaved pBR322 and incubated at $37^{\circ} \mathrm{C}$ for $60 \mathrm{~min}$. Ten-microliter aliquots were prepared and analyzed as in (A). NC indicates omission of DNase I from the reaction mixture. The presence of smears below the discrete band indicates degradation of pBR322 by residual DNase I activity. (C) DNase I was heatinactivated at $95^{\circ} \mathrm{C}$ for $10 \mathrm{~min}$ in PCR buffer containing various concentrations of DTT. The heated DNase I in an amount equivalent to $0.2 \mathrm{U} / 50 \mu \mathrm{L}$ (upper panel) or $1 \mathrm{U} / 50 \mu \mathrm{L}$ (lower panel) before heating was used to digest $100 \mathrm{ng} E c o R I-c l e a v e d ~ p B R 322$ by incubating at $37^{\circ} \mathrm{C}$ for $60 \mathrm{~min}$. Fifteen-microliter aliquots were prepared and analyzed as in (A). PC indicates the omission of DTT from the reaction mixture. 
tion by Zimmerman et al. (10) that elevation of $\mathrm{pH}$ after heat inactivation in acidic conditions restored the activity of DNase I. Our observation that DNase I became reactivated in $\mathrm{pHs}$ higher than 9 has not yet been reported.

As a $\mathrm{pH}$ of 9 was well tolerated by DNA polymerases used for PCR, we tried the whole reaction (i.e., treatment of Taq DNA polymerase by DNase I) and heat inactivation of DNase $\mathrm{I}$ at $95^{\circ} \mathrm{C}$ for $10 \mathrm{~min}$ and $\mathrm{PCR}$, all at $\mathrm{pH} 9$. PCR amplification was not suppressed at all by $0.2 \mathrm{U} / 50 \mu \mathrm{L}$ DNase I heated at $\mathrm{pH} 9$, but was strongly suppressed by DNase I heated at $\mathrm{pH} 7$ or 8 (Figure 2A). Since Bickler et al. (1) reported that DNase I heat-inactivated in $6 \mathrm{mM}$ $\mathrm{Mg}^{++}$was reactivated by incubation in $2 \mathrm{mM} \mathrm{Mg}^{++}$, we checked if the DNase I heat-inactivated at $\mathrm{pH} 9$ in $6 \mathrm{mM} \mathrm{Mg}^{++}$ was reactivated by incubation in $2 \mathrm{mM}$ $\mathrm{Mg}^{++}$buffer. No reactivation occurred (data not shown).

When RT buffer was used in place of PCR buffer in an assay similar to the one shown in Figure 1A, DNase I (1 $\mathrm{U} / 50 \mu \mathrm{L}$ ) was shown to be completely inactivated by heating at $95^{\circ} \mathrm{C}$ for 10 min (data not shown). The critical difference between RT and PCR buffers was the presence of dithiothreitol (DTT) in RT buffer [ $3 \mathrm{mM} \mathrm{MgCl} 2,50$ $\mathrm{mM}$ Tris- $\mathrm{HCl}(\mathrm{pH} 8.3), 75 \mathrm{mM} \mathrm{KCl}$ and $1 \mathrm{mM}$ DTT (Life Technologies, Chyuo, Tokyo, Japan)]. We then heated DNase I at $95^{\circ} \mathrm{C}$ for $10 \mathrm{~min}$ in PCR buffer containing various concentrations of DTT. DNase I $(0.5 \mathrm{U} / 50 \mu \mathrm{L}$; Figure 1C, upper panel) or $1 \mathrm{U} / 50 \mu \mathrm{L}$ DNase I (Figure 1C, lower panel) were completely inactivated when the buffer contained DTT of $0.1 \mathrm{mM}$ or higher. Next, we checked the effect of DTT on the whole PCR. While DNase I, heatinactivated in the absence of DTT, greatly reduced PCR products, DNase I heat-inactivated in its presence did not (Figure 2B). The reducing activity of DTT likely altered the tertiary structure of DNase I, facilitating the heat denaturation. DTT alone had no adverse effect on PCR.

Our data clearly show that heating of DNase I at $95^{\circ} \mathrm{C}$ for $10 \mathrm{~min}$ in PCR buffer is inadequate for inactivation. Heating of DNase I in one-tube RTPCR with a reaction mixture that does not contain DTT $(3,4)$ was also inadequate for inactivation.

DNase I could be heat-inactivated when the $\mathrm{pH}$ of the DNase I solution was lower than 7 or higher than 9 . In this sense, PCR buffer whose $\mathrm{pH}$ is adjusted to 9 in some commercial kits could be more suitable for PCR when heat inactivation of DNase I is needed. DNase I could also be heat-inactivated in buffers containing DTT at concentrations of $0.1 \mathrm{mM}$ or higher.

\section{REFERENCES}

1.Bickler, S.W., M.C. Heinrich and G.C. Bagby. 1992. Magnesium-dependent thermosta-
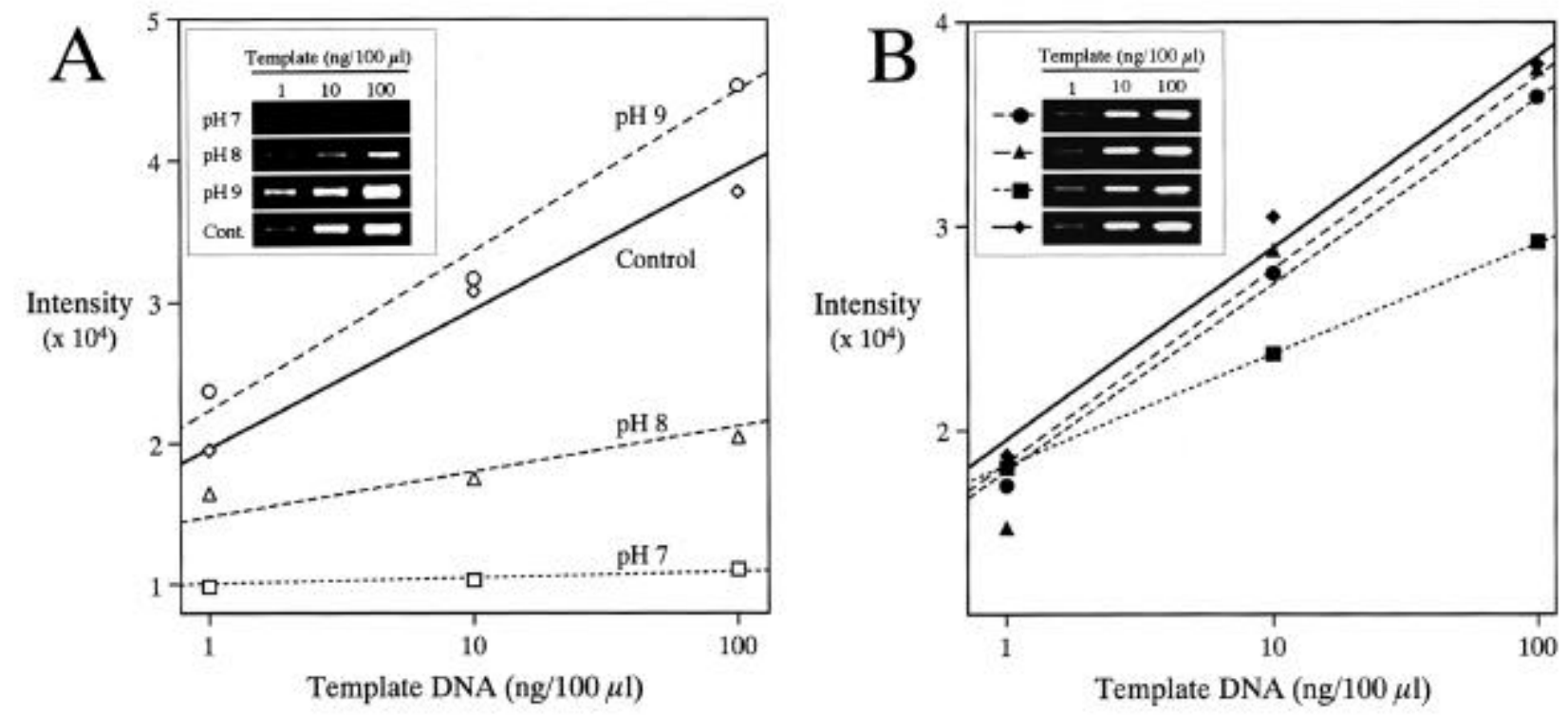

Figure 2. Effect of pH and DTT on PCR amplification in the presence of DNase I. (A) Effect of pH on heat inactivation of DNase I: 10 U Taq DNA polymerase and $4 \mathrm{U}$ DNase I were dissolved in $40 \mu \mathrm{L}$ PCR buffer with pH adjusted to 7, 8 or 9 . The mixtures were incubated at $37^{\circ} \mathrm{C}$ for $30 \mathrm{~min}$ and then heated at $95^{\circ} \mathrm{C}$ for $10 \mathrm{~min}$. As a control, the mixture without DNase I ( $\mathrm{pH} 8.3$ ) was treated similarly. Two microliters of heat-treated Taq DNA polymerase were mixed with a $48-\mu \mathrm{L}$ reaction mixture containing a template, primers and dNTPs. The final composition was heated as follows: DNase I (0 or $0.2 \mathrm{U}), 0.5 \mathrm{U}$ Taq DNA polymerase, $1 \mu \mathrm{M}$ each of primers (5'-ATCTAACAATGCGCTCATCG-3' and 5'-AGGCGCCAGCAACCGCACCT-3') (Sawady Technology, Toshima, Tokyo, Japan), various concentrations of EcoRI-cleaved pBR322, and $200 \mu \mathrm{M}$ dNTPs (GeneAmp dNTPs; PE Biosystems) in $50 \mu \mathrm{L}$ PCR buffer. The mixtures were submitted to a thermal cycling program as described for Figure 1. PCR products in a volume of $15 \mu \mathrm{L}$ were electrophoresed on a $1.5 \%$ agarose gel. The gel was stained with ethidium bromide $(1 \mathrm{mg} / \mathrm{L})$, and the bands were visualized by Foto/Analyst Investigator Eclipse systems. The PCR products were quantified by the histogram analysis using Adobe ${ }^{\circledR}$ Photoshop ${ }^{\circledR} 3.0 .5 \mathrm{~J}$ (Adobe Systems, Shibuya, Tokyo, Japan), pH $7(\square), \mathrm{pH} 8(\triangle)$, pH 9 (O) and control $(\diamond)$. (B) Effect of DTT on heat inactivation of DNase I: $0.5 \mathrm{U}$ Taq DNA polymerase, $0.2 \mathrm{U}$ DNase I and $0.1 \mathrm{mM}$ DTT were dissolved in $20 \mu \mathrm{L}$ PCR buffer. The mixture was heated at $95^{\circ} \mathrm{C}$ for $10 \mathrm{~min}$ and then added to a $30-\mu \mathrm{L}$ reaction mixture containing $0.1 \mathrm{mM}$ DTT, a template, primers and dNTPs. The final mixture was submitted to the thermal cycling program and analyzed as described above $(\bullet)(1)$. DNase I $(\boldsymbol{\Delta})$, DTT $(\boldsymbol{\bullet})$, or both $(\bullet)$ were omitted from the mixture as controls. 
bility of DNase I. BioTechniques 13:64-66.

2.Cusi, M.G., M. Valassina and P.E. Valensin. 1994. Comparison of M-MLV reverse transcriptase and Tth polymerase activity in RTPCR of samples with low virus burden. BioTechniques 17:1034-1036.

3.Fiorenza, M.T. and F. Mangia. 1998. Quantitative RT-PCR amplification of RNA in single mouse oocytes and preimplantation embryos. BioTechniques 24:618-623.

4.Huang, Z., M.J. Fasco and L.S. Kaminsky. 1996. Optimization of DNase I removal of contaminating DNA from RNA for use in quantitative RNA-PCR. BioTechniques 20:1012-1020.

5.Kunitz, M. 1950. Crystalline desoxyribonuclease: I. Isolation and general propertiesSpectrophotometric method for the measurement of deoxyribonuclease activity. J. Gen. Physiol. 33:349-362.

6.Mallet, F., G. Oriol, C. Mary, B. Verrier and B. Mandrand. 1995. Continuous RT-PCR using AMV-RT and Taq DNA polymerase: characterization and comparison to uncoupled procedures. BioTechniques 18:678-687.

7.Rand, K.H. and H. Houck. 1990. Taq polymerase contains bacterial DNA of unknown origin. Mol. Cell. Probes 4:445-450.

8.Rochelle, P.A., A.J. Weightman and J.C. Fry. 1992. DNase I treatment of Taq DNA polymerase for complete PCR decontamination. BioTechniques 13:520.

9.Schmidt, T.M., B. Pace and N.R. Pace. 1991. Detection of DNA contamination in Taq polymerase. BioTechniques 11:176-177.

10.Zimmerman, S.B. and N.F. Coleman. 1971 Pancreatic deoxyribonuclease-The role of dimerization in the reversible thermal inactivation at acid pH. J. Biol. Chem. 246:309-317.

Address correspondence to Ken-ichi Hanaki, Department of Bacteriology, Faculty of Medicine, The University of Tokyo, 7-3-1 Hongo, Bunkyo-ku, Tokyo 113-0033, Japan.e-mail:hanakims@d1.dion.ne.jp

Received 30 June 1999; accepted 21 January 2000.

K. Hanaki, H. Nakatake, $K$. Yamamoto $^{1}$, T. Odawara ${ }^{2}$ and H. Yoshikura ${ }^{2}$

The Chemo-Sero Therapeutic

Research Institute

Kyokushi, Kikuchi-gun

Kumamoto

${ }^{1}$ Laboratory of Clinical

Microbiology and Immunology

Bun'inn Hospital

of University of Tokyo

Tokyo

${ }^{2}$ National Institute

of Infectious Diseases

Tokyo, Japan

\section{Trypan Blue as a Slow Migrating Dye for SSCP Detection in Polyacrylamide Gel Electrophoresis}

BioTechniques 29:42-44 (July 2000)

Bromophenol blue (BPB) and xylene cyanol (XC) are classic dyes used for DNA and RNA gel electrophoresis as indicators of migration distance. Since their migration corresponds to less than $500 \mathrm{bp}$ in polyacrylamide gels, they often run off the gel when we tried to investigate the high molecular weight area of the gel. SSCP with silver staining (SSCP-SS) is an easy, nonradioisotopic method for screening point mutations in known regions of genomic DNA derived from pathology archives, fresh tissues and peripheral blood cells (1). It uses less expensive equipment, such as ordinary $14 \times 14-\mathrm{cm}$ slab gel electrophoresis. It has become one of the best methods for screening the mutation and polymorphism in genetics and molecular epidemiology in the modestly equipped laboratories found often in suburban hospitals. In this technique, single strands of DNA

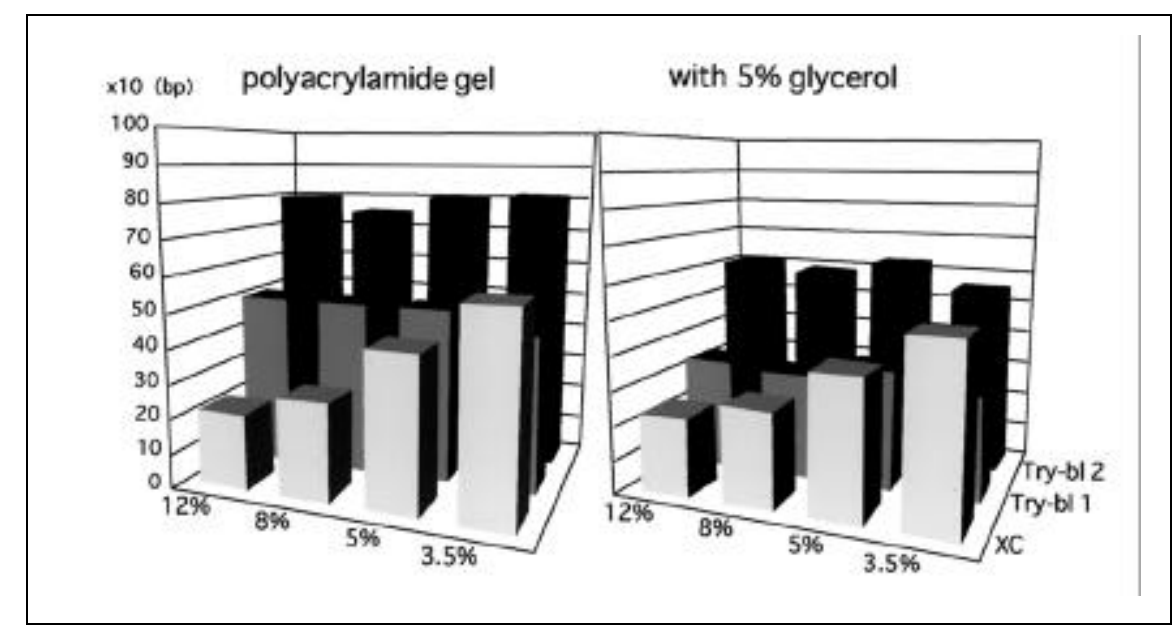

Figure 1. Relative migration distance of three dyes in polyacrylamide gel with and without $5 \%$ glycerol. Basepair was estimated and adjusted by $\phi \mathrm{X}$ 174/HaeIII.

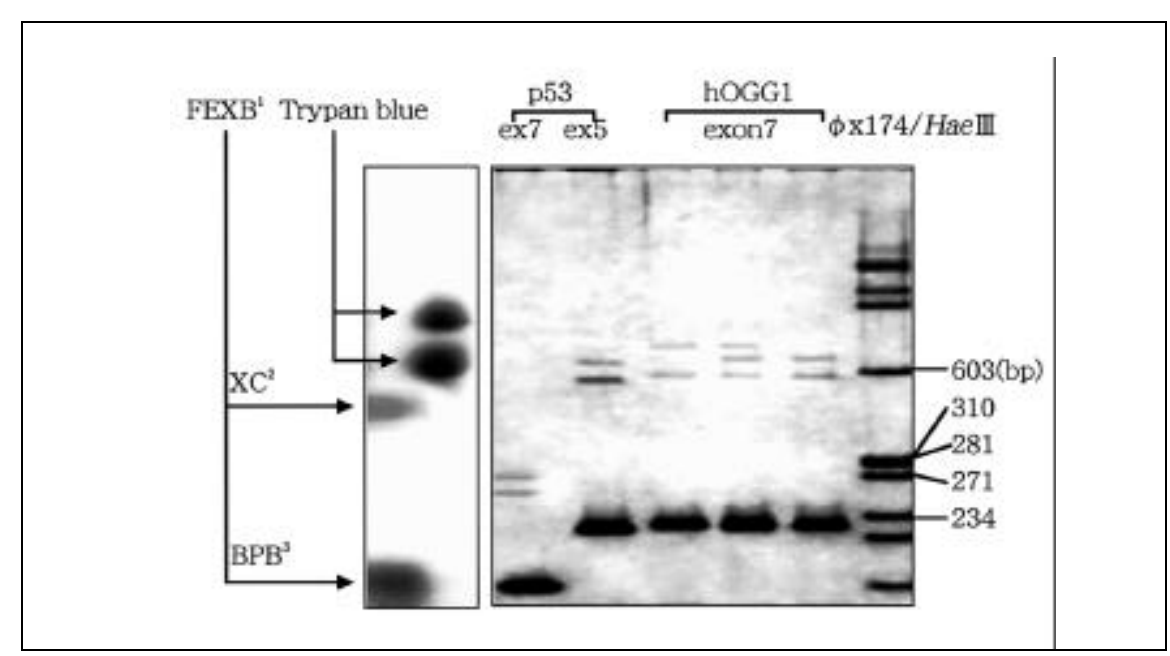

Figure 2. Relative migration distance of BPB, XC (the left lane) and Trypan blue (lane 2). SSCP analysis after visualization using a silver staining kit (Wako, Osaka, Japan) showing p53 exons 7 and 5 and three genotypes of Ser326Cys polymorphism of hOGG1 (exon 7) (2). The rightmost lane is a size marker $\phi X$ 174/HaeIII (Toyobo, Osaka, Japan). 